\title{
Effect of Flower Pollination on Fruit Set and Cropping in Apple
}

\author{
Giannina Vizzotto, Elena Driussi, Maila Pontoni, Raffaele Testolin* \\ Department of Agricultural, Food, Environmental and Animal Sciences, University of Udine, Udine, Italy \\ Email addresses \\ giannina.vizzotto@uniud.it(G. Vizzotto), eledi84@hotmail.it(E. Driussi), pontoni.maila@spes.uniud.it(M. Pontoni), \\ raffaele.testolin@uniud.it(R. Testolin) \\ ${ }^{*}$ Corresponding author
}

To cite this article:

Giannina Vizzotto, Elena Driussi, Maila Pontoni, Raffaele Testolin. Effect of Flower Pollination on Fruit Set and Cropping in Apple. American Journal of Agriculture and Forestry. Vol. 6, No. 5, 2018, pp. 156-161. doi: 10.11648/j.ajaf.20180605.16

Received: August 9, 2018; Accepted: August 23, 2018; Published: October 13, 2018

\begin{abstract}
Apple (Malus x domestica Borkh.), being self-incompatible, requires cross-pollination to set fruit regularly. Apple flowers contain ten ovules and the higher the number of fertilized ovules, the larger the fruit size. In commercial orchards, cross pollination is usually guaranteed by intercropping different cultivars and by introducing beehives in the orchard at flowering time. Despite evidence that pollen donors should be close for successful pollen transportation, apple growers often plant large monovarietal blocks with negative consequences on crop load and fruit size. The contribution of wind and bees to apple pollination was studied and compared with hand-pollination in two apple cultivars, 'Royal Gala' and 'Golden Delicious'. Self-pollination was also included as control. Each treatments was replicated in 120 cymes randomly assigned to plants in the central part of large monovarietal blocks (1.61 and 2.72 ha respectively). Fruit set and fruit weight increased moving from wind-pollination to wind + bee-pollination to hand-pollination as a consequence of the increase in the number of seeds per fruit. Fertilization of a single ovule was enough to set fruit after flowering, but the more seed, the larger the fruit. The increase in fruit weight per additional seed was $2.0 \mathrm{~g}$ for 'Royal Gala' and $4.6 \mathrm{~g}$ for 'Golden Delicious'. This relationship between seed count and fruit weight resulted in fruit set by wind-pollination being mainly in the lower size classes, while wind + beepollination and, largely, hand-pollination shifted the fruit size distribution towards larger size classes. This resulted, in turn, in a dramatic increase in grower income. No significant difference between treatments in fruit quality, as assessed by fruit firmness, soluble solids content, titratable acidity, dry matter and starch content, was observed after fruit storage. It is concluded that limiting pollination in the hope of reducing the labor of thinning is not a good strategy, because flowers set fruit with a minimal cross-pollination, even if only a single seed is produced; conversely, the low seed content of fruit due to insufficient pollination is responsible for great losses for grower in both total crop yield and income.
\end{abstract}

Keywords: Pip Fruit, Self-Incompatibility, Wind Pollination, Bee Pollination, Hand Pollination, Pollenizers, Pollinators

\section{Introduction}

Apple (Malus x domestica Borkh.) is a self-incompatible species, which requires cross-pollination to set fruit regularly $[3,9,10,22,18]$. The incompatibility is of the gametophytic type and is controlled by a single multiallelic locus, the Slocus $[4,15]$. In only a few cultivars is there a very low incidence of selfing [14]. In commercial orchards, compatible pollen supply is either assured by intercropping different cultivars or by introducing crab or ornamental apple trees, grown just as pollen donors (see [15] for a review).
Pollination is carried out either by wind or insects, mainly honeybees and bumblebees. Therefore, many factors related to orchard design and pollenizers' distribution, the presence of beehives, as well as weather conditions during flowering may play crucial roles in fruit set and cropping $[2,5,6,11$, $16,17]$.

The few studies carried out in the past to model pollen dispersal recommend having pollen donors not more than 25 $\mathrm{m}$ from the cultivar to be pollinated [19]; the distance should be reduced to $10-15 \mathrm{~m}$ in intensive orchards trained to slender spindles [20], while occasional pollen transfer at longer distances has been documented [13]. In any case, the 
closer the distance between compatible varieties, the more likely is successful pollination (see [15] for a review). Nevertheless, apple growers often adopt large monovarietal blocks, ignoring the possibility that a reduction in successful pollen dispersal might limit fruit development and crop load. The aim of the present study was to investigate the relative contributions of wind and insects to apple pollination in comparison to controls (no pollination and hand pollination), to evaluate the relationship between seed number and fruit weight, and to provide an economic estimate of the importance of pollination in commercial apple orchards.

\section{Materials and Methods}

Six-year-old plants of 'Royal Gala'(clone 'Obrogala') and 'Golden Delicious (clone 'B'), grafted onto 'M.9' rootstock and trained as slender spindles at a spacing of $4.0 \mathrm{~m}$ between rows and $1.2 \mathrm{~m}$ within rows were studied. 'Royal Gala' was grown in a block of 20 rows $200 \mathrm{~m}$ long (approx. $1.61 \mathrm{ha}$ ) and 'Golden Delicious' in a block of 34 rows $200 \mathrm{~m}$ long (approx. 2.72 ha). Pollenizers were not present in either block. 'Royal Gala' was flanked by 'Golden Delicious', and 'Golden Delicious' by 'Fuji' on both long sides.

Five pollination treatments were compared: 1. selfpollination (bagged cymes); 2. wind pollination (cymes isolated by netting to prevent insect pollination); 3 . wind + bee pollination (free pollination with beehives introduced into the orchard when $50 \%$ of king flowers were open); 4 . hand pollination (bagged cymes with flowers pollinated by hand with pollen collected from either cultivar of the trial pair); 5. hand pollination as above with two fruit left after thinning.

One hundred and twenty cymes were assigned to each treatment, except for self-pollination, which had only twenty cymes. Replicates were randomly assigned to individual trees of the central part of each block. After fruit set, the cymes were thinned leaving only the king fruit, except for the treatment 5 , where two fruit per cyme were retained to assess competition between fruit within an inflorescence. Trees were thinned to $140-150$ fruit tree $^{-1}$, corresponding to approx. 300,000 fruit ha ${ }^{-1}$.

At commercial harvest fruit were collected, individually labelled and stored in a cold room $\left(0 \div 4^{\circ} \mathrm{C}\right)$ for four months. After storage, the following parameters were measured on each fruit: transverse diameter, fresh weight, flesh firmness, soluble solids content, titratable acidity, starch and dry matter content. Seed were also counted.

Variables, either measured or calculated, were statistically analyzed with ANOVA. In the tables the standard deviation of the mean is reported as a measure of variability and the significance $(\mathrm{P})$ of the differences among treatments is given.

\section{Results}

\subsection{Fruit Set and Cropping}

In both cultivars tested, bagged flower clusters, in which cross-pollination was prevented, did not set any fruit (Table 1).

Wind actively contributed to pollen transport across the orchard allowing set of $63.3 \%$ of king fruit in 'Royal Gala', and $46.7 \%$ in 'Golden Delicious'. Honeybees contributed little to pollination, allowing an increase in fruit set of about $10 \%$ in both cultivars, while hand pollination guaranteed a very high percentage fruit set $-85.8 \%$ in 'Royal Gala', and $80.0 \%$ in 'Golden Delicious', respectively. When two flowers per cyme were retained, even if hand pollinated, there was competition between the fruit of each pair, resulting in a lower percentage fruit set of the king flower. However, such a slight reduction was largely counterbalanced by the presence of the second fruit.

Table 1. Effect of pollination method on fruit set and fruit weight at harvesting time, and number of seeds /fruit, fruit firmness and soluble solids content (SSC) after 4 months fruit storage (means \pm std dev, n.r. = not recorded).

\begin{tabular}{|c|c|c|c|c|c|}
\hline Pollination method & Fruit set (\%) & Fruit weight (g) & Seeds/fruit (n) & Firmness $\left(\mathrm{Kg} \mathrm{cm}^{-2}\right)$ & $\operatorname{SSC}(\%)$ \\
\hline \multicolumn{6}{|l|}{ 'Royal Gala' } \\
\hline Isolated & 0 & & & & \\
\hline Wind & 63.3 & $140 \pm 28$ & $3.2 \pm 2.4$ & $7.1 \pm 0.4$ & $11.7 \pm 0.6$ \\
\hline Wind+bees & 72.5 & $142 \pm 23$ & $4.4 \pm 2.9$ & $7.1 \pm 0.5$ & $12.2 \pm 0.7$ \\
\hline Hand single fruit & 85.8 & $155 \pm 22$ & $7.9 \pm 2.2$ & $7.1 \pm 0.4$ & $12.3 \pm 0.6$ \\
\hline Hand central fruit & 87.5 & $148 \pm 21$ & $8.5 \pm 1.5$ & $7.5 \pm 0.6$ & $12.1 \pm 0.8$ \\
\hline $\begin{array}{l}\text { Hand lateral fruit } \\
\text { 'Golden Delicious' }\end{array}$ & 53.3 & $138 \pm 23$ & $7.8 \pm 1.7$ & n.r. & n.r. \\
\hline Isolated & 0 & & & & \\
\hline Wind & 46.7 & $182 \pm 36$ & $1.1 \pm 1.2$ & $5.3 \pm 0.6$ & $14.6 \pm 1.3$ \\
\hline Wind+bees & 56.7 & $187 \pm 39$ & $2.2 \pm 2.0$ & $5.3 \pm 0.5$ & $14.4 \pm 1.3$ \\
\hline Hand single fruit & 80.0 & $226 \pm 40$ & $9.0 \pm 2.0$ & $4.9 \pm 0.5$ & $13.7 \pm 1.0$ \\
\hline Hand central fruit & 82.5 & $223 \pm 43$ & $9.5 \pm 1.9$ & $5.1 \pm 0.6$ & $14.3 \pm 0.9$ \\
\hline $\begin{array}{l}\text { Hand lateral fruit } \\
\text { Two-ways ANOVA }\end{array}$ & 60.8 & $201 \pm 48$ & $9.1 \pm 2.3$ & $5.2 \pm 0.5$ & $14.4 \pm 1.2$ \\
\hline Pollination (P) & & $<0.001$ & $<0.001$ & $<0.001$ & $<0.01$ \\
\hline $\mathrm{CV} \times \mathrm{P}$ & & n.s. & $<0.001$ & $<0.01$ & $<0.001$ \\
\hline
\end{tabular}




\subsection{Fruit Weight and Seed Number}

The method of pollination significantly affected fruit size and weight, the effect being more evident in 'Golden Delicious' which genetically produces larger fruit than 'Royal Gala' (Table 1). The average number of seed per fruit was proportional to fruit size (fruit developing from king flowers), ranging from 3.2 to 7.9 seed fruit ${ }^{-1}$ in 'Royal Gala', and from 1.1 to 9.0 seed fruit $^{-1}$ in 'Golden Delicious', with the lowest values recorded for wind-pollinated fruit and the highest for hand-pollinated fruit (Table 1).

Overall, considering all fruit and all treatments, the number of seed ranged from 0 to 14 . The few fruit with no seed were discarded before analysis, because it is likely that seed were initially present during fruit growth, but subsequently aborted. Likewise, the few fruit with 13 or 14 seed were also excluded from analysis because their very low occurrence made statistical analyses less reliable.

\subsection{Effect of Pollination on Fruit Quality}

In general, no difference was observed in fruit firmness and soluble solids content among treatments after four months of storage (Table 1). Other characteristics, such as titratable acidity, starch and dry matter content, did not show significant differences among treatments and are not reported.

\section{Discussion}

In 'Golden Delicious' and 'Royal Gala' blocking crosspollination prevented fruit set. This confirms that apples are predominantly self-incompatible since they do not usually set fruit without pollen carrying different self-incompatibility alleles [4]. The few fruit containing no seed, when assessed after storage, probably resulted from embryo or seed abortion during the later phases of development, as reported by other authors [10, 22].

Generally, fertilization of a single ovule allowed fruit set and growth throughout the whole season, but the higher the number of seed the larger the fruit size and the greater the weight (Figure 1). There was a clear linear correlation between seed number and fruit weight. As expected, the increase in fruit weight for each additional seed was greater in 'Golden Delicious' than in 'Royal Gala' (4.6 vs. $2.0 \mathrm{~g}$ ), since 'Golden Delicious' produces inherently larger fruit. As previously reported $[10,23,1,17]$, the gain in weight per additional seed was small. In a similar experiment Blažek and Hlušičková reported, for instance, an increase of $3.2 \mathrm{~g}$ fruit weight per additional seed in 'Golden Delicious' [1]. Although the observed increase in fruit weight, due to the increased seed number, was low, it still had a dramatic consequence on grower income, since larger fruit receive higher prices.

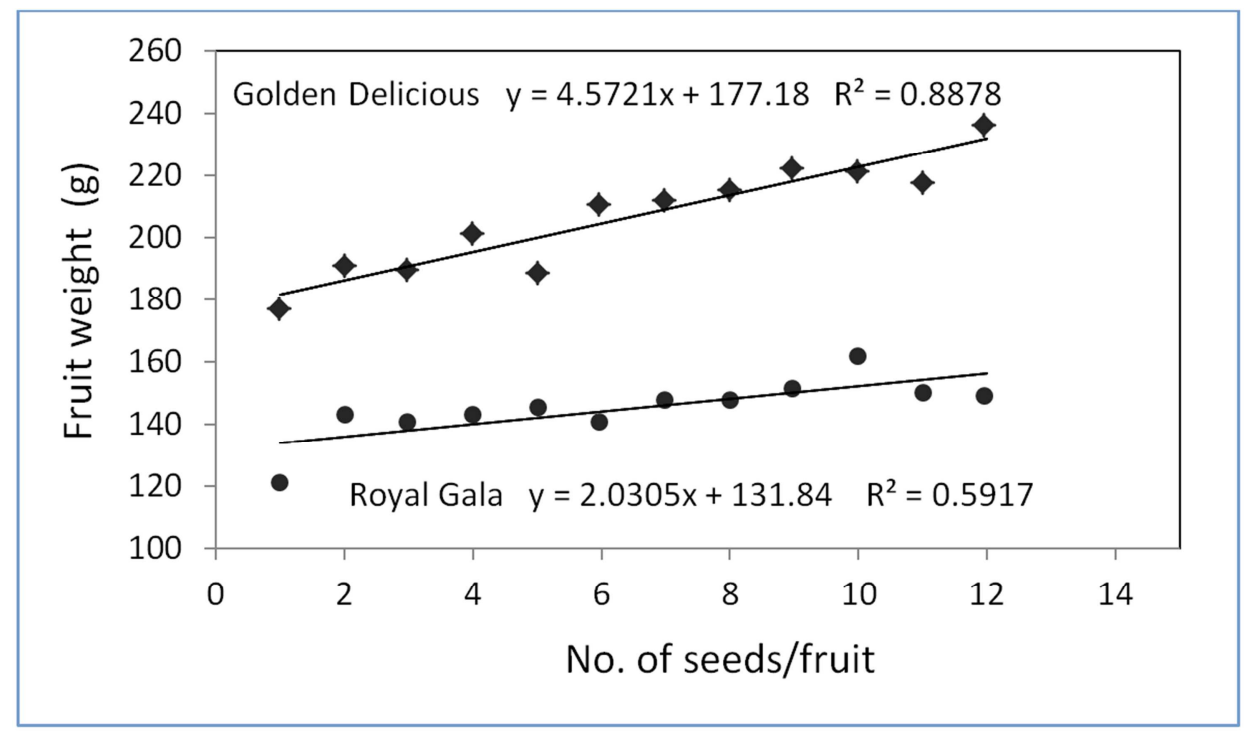

Figure 1. Relationship between the number of seed/fruit and fruit weight. ( $\bullet$ 'Golden Delicious'; (•) 'Royal Gala'. Fruit with no seed or with 13 or more seed were excluded from this analysis.

To estimate the impact of the differences in fruit weight reported in Table 1 on grower revenue, harvested fruits were individually assigned to a size class, as categorized by dealers, and the percentage of fruit falling into each different size class was calculated for each cultivar and each treatment. In both cultivars, there was a clear shift in fruit size towards the larger size classes from the wind pollination treatment to the wind + bee pollination treatment to hand pollination (Figure 2). A price list, averaged over those of three main Italian apple traders over the last two years, was then adopted (Table 2) and the total production and gross income were calculated for each treatment, assuming a potential of 300,000 fruit ha ${ }^{-1}$ after commercial thinning (Table 3 ). 

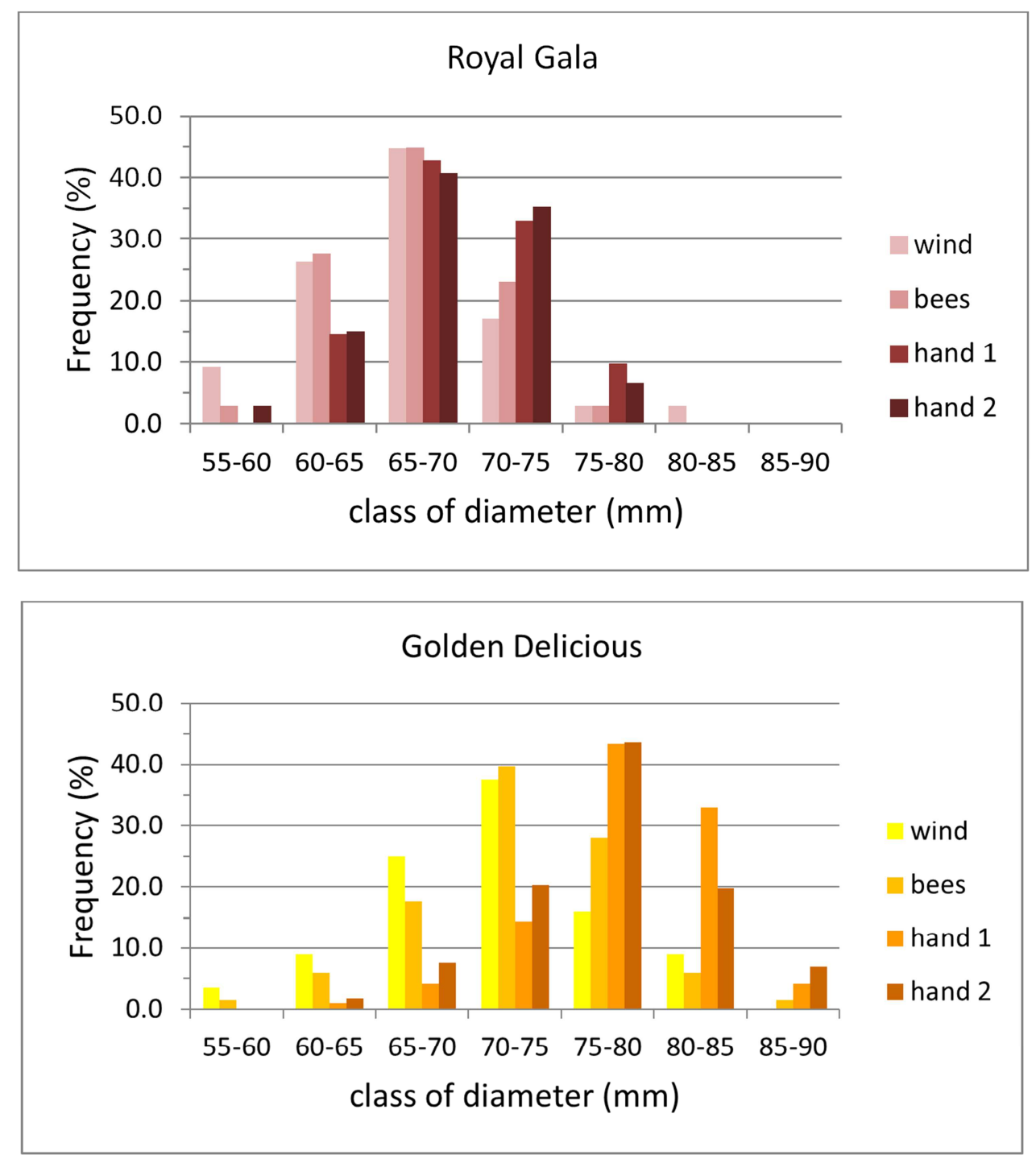

Figure 2. Distribution by size (class of diameter, mm) of fruit populations according to the pollination method. (top) 'Royal Gala'; (bottom) 'Golden Delicious'. 'Bees' means wind + bees; 'hand 1' refers to hand pollination of the single king flower; 'hand 2' refers to hand pollination of two flowers/cyme.

Table 2. Prices ( $€ \mathrm{~kg}^{-1}$ ) received for different fruit size classes (mm diameter). Data were averaged over three different dealers and two consecutive years and were used to estimate grower gross income using different pollination treatments.

\begin{tabular}{lll}
\hline Size class $(\mathbf{m m})$ & 'Royal Gala' $\left(\boldsymbol{€} \mathbf{~ k g}^{-\mathbf{1}}\right)$ & 'Golden Delicious' $\left(\boldsymbol{€} \mathbf{~ k g}^{-\mathbf{1}}\right)$ \\
\hline$<65$ & 0.05 & 0.00 \\
$65-70$ & 0.27 & 0.06 \\
$70-75$ & 0.41 & 0.16 \\
$75-80$ & 0.47 & 0.29 \\
$80-85$ & 0.52 & 0.37 \\
$85-90$ & 0.52 & 0.39 \\
$>90$ & 0.53 & 0.39 \\
\hline
\end{tabular}

In spite of the limits of such a simple simulation, the great impact of the apparently small differences in mean fruit weight of Table 1 on fruit size distribution and, in turn, on grower revenue is undoubtedly clear, most obviously for 'Golden Delicious' which potentially produces larger fruits when good pollination is guaranteed.
Table 3. Estimated production $\left(t h a^{-1}\right)$ and grower revenue for different pollination treatments $\left(€ h a^{-1}\right)$.

\begin{tabular}{lllll}
\hline \multirow{2}{*}{ Pollination method } & \multicolumn{2}{l}{ 'Royal Gala' } & \multicolumn{2}{c}{ 'Golden Delicious' } \\
\cline { 2 - 5 } & $\mathbf{t ~ h a}^{-\mathbf{1}}$ & $\boldsymbol{\epsilon} \mathbf{~ h a}^{-\mathbf{1}}$ & $\mathbf{t ~ h a}^{-1}$ & $\boldsymbol{\epsilon ~ h a}^{-\mathbf{1}}$ \\
\hline Wind & 21.6 & 5,304 & 25.1 & 4,469 \\
Wind + bees & 25.4 & 6,659 & 32.3 & 6,560 \\
Hand & 36.3 & 11,752 & 54.8 & 16,596 \\
\hline
\end{tabular}

Data for 'Royal Gala' showed that the theoretical production obtained with 300,000 wind-pollinated fruits equaled 21.6 tons $\mathrm{ha}^{-1}$ corresponding to an income of $€ 5,304$ $\mathrm{ha}^{-1}$; the same number of fruits obtained by wind + beepollination resulted in 25.4 tons $\mathrm{ha}^{-1}$ corresponding to an income of $€ 6,659 \mathrm{ha}^{-1}$, while hand pollination resulted in 36.3 tons $\mathrm{ha}^{-1}$ and an income of $€ 11,752 \mathrm{ha}^{-1}$. The differences for 'Golden Delicious' were even more remarkable, ranging from 25.1 tons $\mathrm{ha}^{-1}$ and $€ 4,470 \mathrm{ha}^{-1}$ for wind-pollinated fruit, to 32.3 tons $\mathrm{ha}^{-1}$ and $€ 6,560 \mathrm{ha}^{-1}$ for wind + bee-pollinated fruit, to 54.8 tons $\mathrm{ha}^{-1}$ and $€ 16,596 \mathrm{ha}^{-}$ ${ }^{1}$ for hand-pollinated fruit (Table 3). 


\section{Conclusions}

Hand pollination is not practicable and cannot realistically be recommended. However, the hand-pollination treatment shows just how much greater could be the potential production of an ordinary apple orchard if pollination is not limiting fruit set and cropping.

It is likely that the low fruit set and the low fruit weight obtained in the wind-pollination treatment was due, in part, to the large single cultivar blocks selected for the trial, blocks that are typical of the area in which the trial was carried out.

In the present experiment beehives were introduced into the orchard at mid flowering, but this did not always result in a large increase in fruit set or fruit size. It could be that the bees introduced were attracted away to other flowering plants or that wild pollinators were not common. Insects other than honeybees, such as bumblebees and Osmia spp., could be more effective in apple pollination, because they fly earlier in the season, are more tolerant of inclement weather, and are prone to forage on apple $[8,21,12]$.

Designing large single-cultivar blocks and paying little attention to pollination with the aim of reducing the necessity to thin both appear misguided because a single or a few seed are sufficient to allow fruit setting at percentages very much higher than the 10-30\% recommended for good fruit sizing [12]. Furthermore, having only a small number of seed in each, fruit results smaller.

Growers have two contrasting concerns about fruit set, the need for thinning if too many fruit are set, and maximising fruit size, which is necessary for good returns. Limiting pollination in the hope of reducing the labor of thinning is not a good strategy, because flowers develop into fruit with minimal crosspollination [2]. Improving fruit size through an increase of seed number without increasing the percentage of fruit set could instead be achieved by restricting pollination to when the king flower is open [7]. This is what growers attempt by introducing beehives at the beginning of flowering and removing them when lateral flowers open and by adopting artificial application of pollen collected in advance from compatible cultivars (see [15] for a review). Similar experiments have recently been attempted using drone-aided pollination at the opening of king flowers (https://www.rotordronemag.com/drones-pollinate-apple-trees/).

\section{Acknowledgements}

The authors thank the Regional Administration for permission to carry out the trial in the ERSA Agricola Experimental Farm, Pantianicco (Udine, Italy) and thank Giorgio Comuzzo and Renato Frezza for assistance in collecting field data and laboratory analyses.

\section{References}

[1] Blažek, J. and I. Hlušičková (2006) Seed count, fruit quality and storage properties in four apple cultivars. J. Fruit Ornam. Plant Res. 14 (Suppl. 2), 151-160.
[2] Brain, P. and J. J. Landsberg (1981) Pollination, initial fruit set and fruit drop in apples: analysis using mathematical models. J. Hort. Sci., 56, 41-54.

[3] Brittain, W. H. and C. C. Eidt (1933) Seed content, seedling production and fruitfulness in apples. Can. J. Res. 9, 307-333.

[4] Broothaerts, W., G. A. Janssens, P. Proost and W. F. Broekaert (1995) cDNA cloning and molecular analysis of two selfincompatibility alleles from apple. Plant Mol. Biol. 27, 499511.

[5] Degrandi-Hoffman, G., R. A. Hoppingarner and R. Pulcer (1986) REDPOL: a pollination and fruit set prediction model for 'Delicious' apples. Environ. Entomol. 16, 309-318.

[6] Dennis, F. G. Jr (1986) Apple. In Monselise, S. P. (ed.): Handbook of fruit set and development. CRC Press Inc., Boca Raton, USA, 1-44.

[7] Ferree, D. C., Bishop, B. L., Schupp, J. R., Tustin, D. S. and W. H. Cashmore (2001) Influence of flower type, position in the cluster and spur characteristics on fruit set and growth of apple cultivars. J. Hort. Sci. Biotech., 76, 1-8.

[8] Heinrich, B. (1976). The foraging specializations of individual bumblebees. Ecol. Monogr 46, 105-128.

[9] Janick, J., J. N. Cummins, S. K. Brown and M. Hemmat (1996) Apples. In: Janick J. and J. N. Moore (eds.): Fruit breeding, Vol. II. Tree and tropical fruits. Wiley, N. Y., 1-76.

[10] Keulemans, J., A. Brusselle, R. Eyssen, J. Vercammen and G. van Daele (1996) Fruit weight in apple as influenced by seed number and pollinizer. Acta Hortic. 423, 201-210.

[11] Kron, P., Husband, B. C., Kevan, P. G. and S. Belaoussoff, S. (2001) Factors affecting pollen dispersal in high-density apple orchards. HortScience 36, 1039-1046.

[12] Ladurner, E., L. Recla, M. Wolf, R. Zelger and G. Burgio (2004) Osmia cornuta (Hymenoptera Megachilidae) densities required for apple pollination: a cage study. J. Apicultural Res. $43(3), 118-122$.

[13] Larsen, A. and E. Kjær (2009) Pollen mediated gene flow in a native population of Malus sylvestris and its implications for contemporary gene conservation management. Conserv. Genet. 10, 1637-1646.

[14] Lespinasse, Y. (1992) Le Pommier. In: Gallais A. and H. Bannerot (eds.): Amélioration des espèces végétales cultivéesobjectifs et critéres de sélection. INRA, Paris, 579-594.

[15] Ramírez, F. and T. L. Davenport (2013) Apple pollination: A review. Sci. Hortic. 162, 188-203.

[16] Sharma, H. K., Gupta, J. K. and J. R. Thakur (2004) Effect of bee pollination and polliniser proportion on apple productivity. Acta Hortic. 662, 451-454.

[17] Sheffield, C. S. (2014) Pollination, seed set and fruit quality in apple: studies with Osmia lignaria (Hymenoptera: Megachilidae) in the Annapolis Valley, Nova Scotia, Canada. J Pollination Ecol 12 (13): 120-128.

[18] Sheffield, C. S., Ngo, H. T. and N. Azzu (2016) A manual on apple pollination. F. A. O. Rome: pp. 45.

[19] Soltész, M. (1996) The placement of different cultivars in apple orchards (in Hungarian). Kerteszeti Tudomany 28 (3-4), 38-40. 
[20] Soltész, M. (1997) The location of varieties in apple orchards. Acta Hortic. 437, 441-443.

[21] Vicens, N. and J. Bosch (2000) Pollinating efficacy of Osmia cornuta and Apis mellifera (Hymenoptera: Megachilidae, Apidae) on 'Red Delicious' apple. Environ. Entomol. 29: 235-240.
[22] Volz, R. K., D. S. Tustin and I. B. Ferguson (1996) Pollination effects on fruit mineral composition, seeds and cropping characteristics of 'Braeburn' apple trees. Sci. Hortic. 66 (3-4), 169-180.

[23] Ward, D. L., Marini, R. P. and R. E. Byers (2001) Relationships among day of year of drop, seed number, and weight of mature apple fruit. HortScience 36, 45-48. 